\title{
Fifth Grade Students' Creative Thinking in Solving Open-Ended Mathematical Problems
}

\author{
Madha Lely ${ }^{1}$, Zetra Hainul Putra ${ }^{1 *}$, Syahrilfuddin ${ }^{1}$ \\ ${ }^{1}$ Faculty of Teacher Training and Education, University of Riau, Pekanbaru, Indonesia \\ *zetra.hainul.putra@lecturer.unri.ac.id
}

Revised: February $10^{\text {th }}, 2020$

Accepted: February $14^{\text {th }}, 2020$

\begin{abstract}
The purpose of this study is to find out how fifth-grade students apply creative thinking abilities to solve open-ended mathematical problems The study was conducted with 19 fifth grade students from a public school in a rural area, Kampar, Indonesia. The data were collected by giving 10 open-ended mathematical problems on whole numbers, fractions, and geometry and measurement. Creative thinking abilities of fifth-grade students in solving open-ended mathematical problems view from three indicators; fluent thinking, flexible thinking and original thinking. The results show that the average ability of students' creative thinking was 23.68. This means that students' creative thinking was poor or less creative.
\end{abstract}

Keywords: creative levels; creative thinking; fifth grade students; open-ended mathematical problems

\section{INTRODUCTION}

In learning mathematics, students are not only required to be active in class but are also required to be able to solve a problem-oriented to their thinking abilities. Many students think that mathematics is complicated and frightening, even though mathematics can predict student success in their future studies and lives (Siegler et al., 2012). In learning mathematics, students are generally only required in mastering material or concepts that sometimes tend to emphasize procedural aspects such as memorizing formulas and processes in solving mathematical problems. The limitations of student memory make students tend to memorize formulas and ways of solving that are considered necessary. Meanwhile, students should not only rely on their memory skills, but they must improve their thinking skills, and one of them is the ability to think creatively.

Every student has creative potential since the student is born, but what needs to be considered is they need a learning environment that they can make a place to develop their creative potential optimally in solving a problem. Mathematics is a basic science that plays a vital role in problem-solving skills, so students are trained to think critically and creatively. Following the objectives of learning mathematics according to Kementrian Pendidkan Nasional 
Regulation No. 22 of 2006 which states that mastery of mathematics is not only limited to the mastery of mathematical facts and procedures as well as understanding concepts, but also in the form of students' process abilities such as reasoning, communication, mathematical connections, logical thinking abilities, analysis, systematic, critical, creative, ability to cooperate and to solve problem. Therefore, we must realize the process of learning mathematics, which leads to the development of students' creative thinking.

Mathematics learning needs to be modified from what has been applied so far. An ability to think creatively and innovatively and the ability to solve problems is a fundamental skill that is absolutely needed in the 21st century (Cropley in Wijaya, 2012: 56). Therefore, educators should place creativity as one of the goals in learning, because creativity is one of the assets for the world of work in the future that students must have.

The ability to think creatively is an embodiment of higher-order thinking skills because these abilities are the highest cognitive competencies that students must master in class. The ability to think creatively can be learned and trained through the habits of these students. The ability to think creatively is indeed a natural ability or potential possessed by humans, but we must also understand that creative thinking is also a natural process that we can improve through awareness and practices (Adam \& Hamm in Wijaya, 2012: 55). Creative thinking is a process that is used when we come up with a new idea. It combines ideas that have not been used before. Creativity is a product of one's creative thinking. Mathematical creative thinking refers to the ability to produce new, varied solutions to open-ended mathematical problems.

Several criteria can assess the ability to think creatively. The criteria are flexible thinking, fluent thinking, original thinking and elaboration ability (Munandar in Wulandari, 2017). Openended questions are used to find out students' creativity. In the pursuit of mathematics we can use questions in the form of open-ended problems, where these problems require students to see a problem and a variety of perceptions to allow various ways to find the right answer so that open-ended problems can be used to find out the students' creative thinking abilities. From research conducted by Wulandari (2017), it was found that there was an increase in students' creative thinking skills about fractions after applying learning with an open-ended approach. Therefore, the researcher wants to know how the students' mathematical creative thinking abilities in solving open-ended problems do not only depend on fractions but also positive integers and 2-D shapes. The formulation of this research is "How is fifth-grade students' creative thinking ability in solving open-ended mathematical problems?" 


\section{THEORETICAL FRAMEWORK}

\section{a. Creative thinking}

Students are one of the human resources who still need to be educated and trained to be able to develop and have creative thinking. Competence of creative thinking for students is critical in the era of global competition because the level of complexity of the problems in all aspects of modern life is getting higher. Creative thinking is classified as high order competencies and can be seen as a continuation of basic competencies in learning mathematics.

Creative thinking is a thought that seeks to create new ideas (Harriman in Wulandari, 2017). Creative thinking can also be interpreted as an activity that someone uses to be able to develop or build new ideas or ideas. Creative thinking is often called divergent thinking, where this thought provides various possible answers to the same question (Halpren in Wulandari, 2017). Creative thinking is closely related to creativity because it is the product of one's creative thinking.

Creativity is the ability to create, and it is considered by a handful of people as an ability that generates new ideas or fresh insights. Creativity can also be interpreted as a process that produces something. In the context of creative thinking, the term creativity is used to refer to the ability of individuals who rely on their uniqueness and expertise to produce new ideas and insights that are fresh and valuable to the individual himself.
Creativity is the process of personal qualities possessed by an individual to create something new with the abilities possessed by the individual. Meanwhile, if it is connected with mathematics learning, with creativity students can develop mathematical concepts that are learned by them to create mathematical concepts that will make it easier to understand mathematics learning.

Creative thinking is an ability that someone has since one is born, but it is not necessarily there without practice and habituation. To assess the ability to think creatively one can use references that have been used. Munandar (in Wulandari, 2017) suggested that the ability to think creatively can be seen from the following aspects:

1) Fluent thinking or fluency that causes a person to be able to spark lots of ideas, answers, problem solving or questions.

2) Flexible thinking or flexibility that causes a person to be able to produce ideas, answers or questions that vary.

3) Original thinking that causes a person to be able to give birth to new and unique expressions or be able to find unusual combinations of common elements.

4) Elaboration ability which causes a person to be able to enrich and develop an idea.

Creative thinking abilities can be classified into four levels, as follows:

1) Level I (less creative) is a low level of creative thinking because 
students only express awareness to complete the given task.

2) Level II (quite creative) shows a higher level of creative thinking because students not only have awareness in completing the task, but students show how they observe the task to provide a slightly different completion.

3) Level III (creative) shows the next higher level of creative thinking because students must choose a strategy and coordinate various explanations in the task and present a logical and systematic sequence of actions in completing the task.

4) Level IV (very creative) is the highest level of creative thinking because students must test productive traits with a set of goals. Explain conclusions about successes or difficulties during the development process.

\section{b. Open-ended approach}

Open-ended approach is one of the first mathematics education innovation efforts undertaken by Japanese mathematics education experts (Nohda in Ruslan \& Santoso, 2013). This approach was 61stablished twenty years ago from research conducted by Shimada, Yashimoto, and Shibuya. According to Suherman (in Fathurrohman, 2018: 118119), in open-ended learning there needs to be activities that build interaction between mathematics and students, so there is openness between the activity of mathematics and student activities and inviting students to answer problems through various strategies.

According to Becker and Epstein (in Wijaya, 2012: 63), a problem can be open in three possibilities, namely: 1) an open process when the problem emphasizes different ways and strategies in finding the right solution, so it has many ways or diverse and correct settlement solutions. This type of problem still has one single solution. 2) The final result being open is when the questions have different final answers. 3) A strategy to develop an open question, namely when the problem emphasizes how students can develop new questions based on initial problems (core problems) that were given.

Shimada and Backer (in Fathurrohman, 2018: 113) define openended models are mathematical learning models that present a problem that has more than one method or solution. So that open-ended questions are formulated to have many correct solutions. Open-ended mathematical problems can be grouped into two types, namely 1) Problems with one answer but many strategies to solve them, namely problems given to students who have many solutions/ ways of solving but have one answer; (2) Problems are many ways of solving and also many answers, namely problems given to students who in addition have many solutions / ways of solving, but also have many answers.

Shimada (in Ruslan \& Santoso, 2013) said that giving open-ended tasks in mathematics learning can stimulate students' intellectual abilities and 
experiences in the process of discovering something new. The tasks provide opportunities for students to provide many answers with different problemsolving strategies. The teacher can detect students' thinking abilities, especially creative thinking where students are required to be creative in solving problems given with various solutions to solve them correctly and appropriately.

Swada (in Wijaya, 2012: 61-62) mentions five benefits of using openended problems. First, students become more actively participating in learning and more often express their ideas. Second, students have more opportunities to use mathematical knowledge and skills comprehensive. Third, each student can freely give a variety of different responses to the problems they are working on. Then, the use of open-ended problems provides reasoning experiences to students. The last one, open-ended questions provide rich experiences for students to carry out discovery activities.

\section{METHODS}

This research is a case study of fifthgrade students at a public school in a rural area, Kampar, Indonesia. The subjects were 19 students, 12 girls and 7 boys. The data collection technique used is the open-ended question test method, which consists of 10 questions about whole numbers, fractions, geometry and measurement. Before the tests were given to the subjects, they were first tested to five students from different groups. After that, the questions are evaluated and revised according to the results of the pilot test.

The data analysis was conducted by scoring students' answers based on the indicators and descriptors on each question. The results of the study were then described according to the actual situation without overdoing and manipulating data. The criteria for the level of creative thinking ability in solving open-ended type math problems based on the assessment benchmarks are presented in table 1.

Table 1. The criteria for the level of creative thinking

\begin{tabular}{cc}
\hline Score & Category \\
\hline $75<N \leq 100$ & Super creative \\
$50<N \leq 75$ & Creative \\
$25<N \leq 50$ & Quite creative \\
$0<N \leq 25$ & Less creative \\
\hline
\end{tabular}

\section{RESULT}

From the results of the study, we found three levels of fifth grade students' creative thinking. None of the students achieves the level of super creative. The students only achieve up to the level of creative.

Table 2 presents the summary of the levels of students' creative thinking. More than $60 \%$ of the students are less creative, and only 1 student could 
achieve the level of creative. The average score of students' creative thinking is 23.68 , and it indicates that the students are really less creative.

Table 2. Recapitulating of Fifth Grade Students' Creative Thinking in Solving Open-Ended Mathematical Problems

\begin{tabular}{ccccc}
\hline Score & Category & Total Students & Average & Percentage \\
\hline $75<x \leq 100$ & Super creative & - & - & - \\
$50<x \leq 75$ & Creative & 1 & 70 & 5.26 \\
$25<x \leq 50$ & Quite creative & 6 & 33.69 & 31.57 \\
$0<\mathrm{x} \leq 25$ & Less creative & 12 & 14.81 & 63.15 \\
\hline Total & $\mathbf{1 9}$ & & $\mathbf{1 0 0 \%}$ \\
Average & $\mathbf{2 3 . 6 8}$ & & Less creative \\
\hline
\end{tabular}

On the next subsection, we describe some examples of students' creative thinking from each level. This aims to show how students present their thinking on their written answers.

\section{a. Students with creative thinking}

There is only one student categorized in this level, namely MAN (Pseudonym). MAN obtains the score of 70 (the maximum score is 100). One example of his work is presented on figure 1 . The problem can be translated as follows:

Mrs. Ina wants to buy $2 \mathrm{~kg}$ of wheat to make cakes. In the grocery, there are several dosages of wheat that can be seen on the figure below:

$1 \mathrm{~kg}$ of wheat,

$1 / 2 \mathrm{~kg}$ of wheat, and

$1 / 4 \mathrm{~kg}$ of wheat

Show us, how many different ways

can Mrs. Ina use to get $2 \mathrm{~kg}$ of wheat?

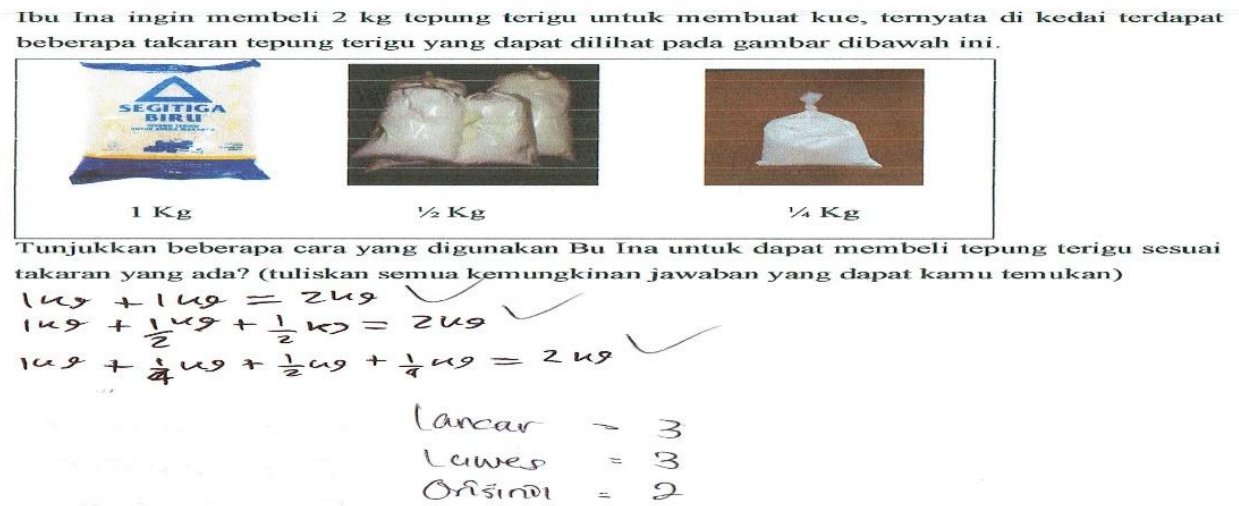

Figure 1. MAN's answers to question number 6 
MAN gave three different answers (Figure 1). He gave all correct answers, and we categorize him into fluent thinking. In the flexible thinking, he gave three different answers, and therefore he got score 3. MAN got score 2 for the original thinking because some given answers were different from other students.

\section{b. Students with quite creative thinking}

Six students are categorized as quite creative (Figure 2). These students can solve the questions but they do not give complete answers.

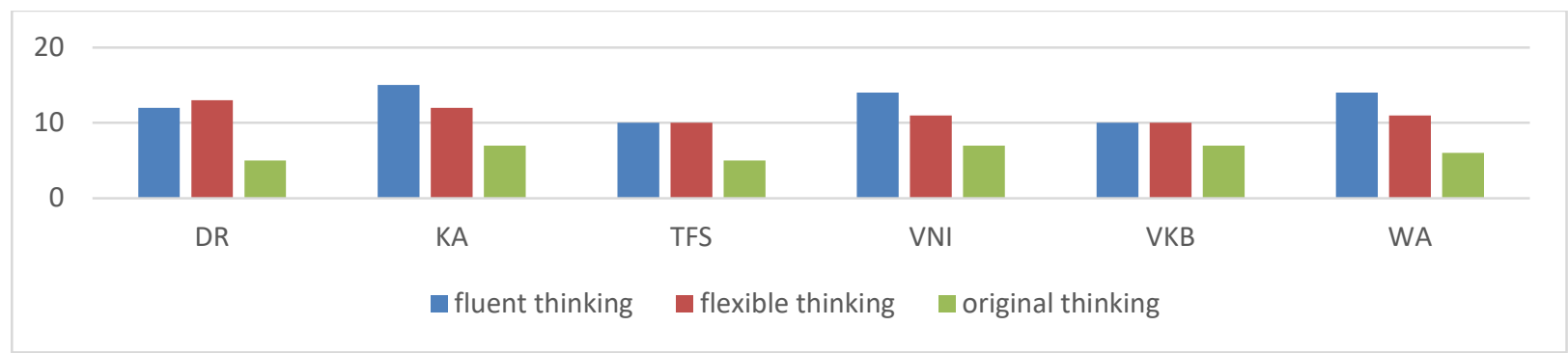

Figure 2. Students with quite creative thinking

Based on figure 2, the highest score on the ability to fluent think is 15 with an average of 12.5. This suggests that students with insufficient level of creative are only able to acquire a half of the maximum score. The highest score of students' flexible thinking ia is 13 and an average of 11.16. While the students were only able to achieve 7 for the original thinking, and this score is less than one-fourth of the maximum score. This means that the students with quite creative thinking level is still low in the ability to think original. The ability to think original is seen from the different of students' answers from others.

In figure 3, we present an example of students' quite creative. The problem is translated as follows:

A student does a mathematics task. He gets the result from the operation as 36. Show us, how many ways the student can use to get 36 ? (Hint: 30 can be $3 \times 10,15+15,40-10$, or 60 : 2).

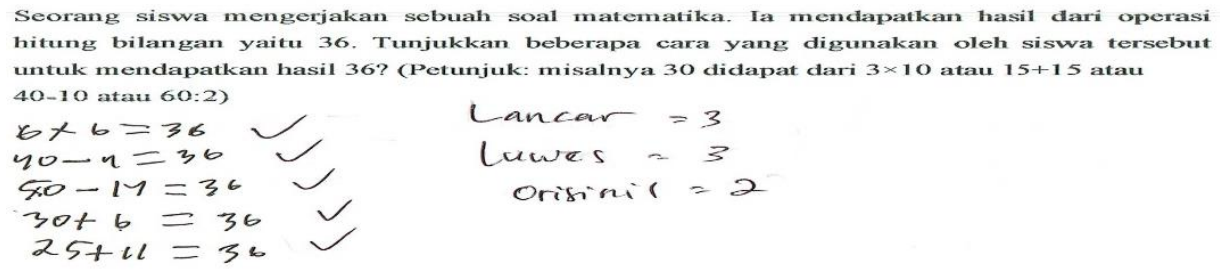

Figure 3. KA's answers for question number 3 
KA gives five different answers (Figure 3). All the answers are correct, so KA could think fluently. In the process of flexible thinking, KA use three different operation sign, addition, subtraction, and multiplication. While in the thinking process of the original students earns a score of two, because of the five answers given there are the same answers with other students.

\section{c. Students with less creative thinking}

Twelve students belong to the less creative category. This means that more than a half of students could not give sufficient answers to the given questions.

Judging based on the indicators of creative thinking students with a level of less creative is very low in the process of thinking. Figure 4 presents the summary of students with less creative thinking.

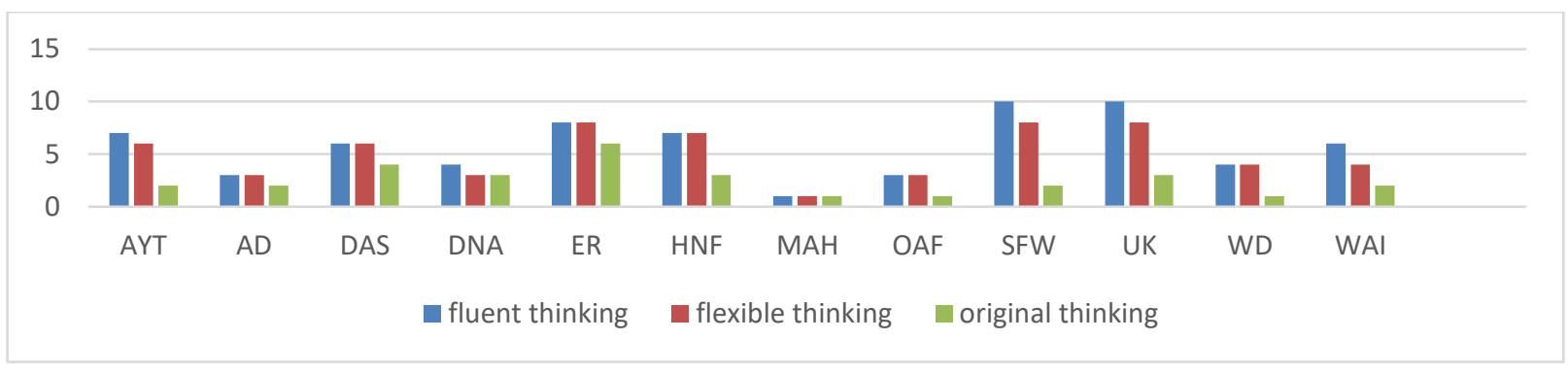

Figure 4. Students with less creative thinking

Based on figure 4, the highest score earned by students with a level of less creative in the ability to think fluently is 10 and the lowest score of 1 with an average of 5.75 . While the ability to think flexibly score highest achieved is 8 and the lowest of 1 with an average of 5.08 and in the ability to think original the highest score obtained by the student is 6 and lowest is 1 with an average of 2.5.
In figure 5, we present an example of students' less creative. The problem is translated as follows:

A student does a mathematics task.

He gets the result from the operation as 36. Show us, how many ways the student can use to get 36 ? (Hint: 30 can be $3 \times 10,15+15,40-10$, or 60 : 2). 


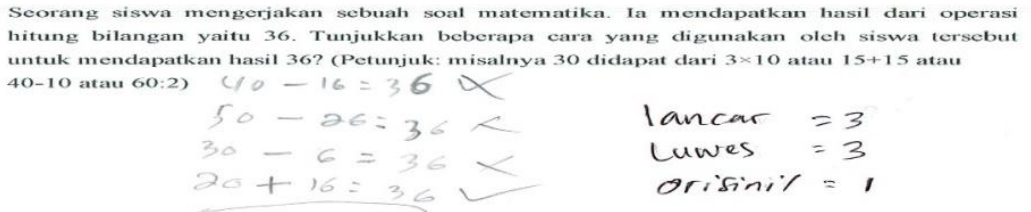

Figure 5. UK's answers for question number 3

In figure 5 , UK gives three correct answers, so as to obtain a score of three on the fluent thinking. In the process of flexible thinking, UK gives three correct answers, so UK earns a score of 3 . While in the thinking process of the original students earns a score of 1 , because three of given answers are the same as others.

\section{DISCUSSION}

Creative thinking abilities of fifth grade students in solving open-ended mathematical problems are in the level of less creative with average $23.68 \%$, it is proving that the ability of students in analyzing the problem is still low. This study is in accordance with the results of research conducted by Witri, Putra, and Gustina (2014) that fifth grade students have low mathematical achievement in solving mathematical tasks based on TIMSS. This could be explained by the fact that the students never get the similar tasks in their daily learning activities.

Many students in this study are in the category of less creative, because the students mostly give one correct answers. Although most students are in the category less creative, some of them begin to manifest the ability to think creative answering some questions with different ideas and techniques. It is proved that the granting of open-ended questions give freedom to the students in providing answers to the given problems. Students freely give answers with different ways in accordance with the concept of learning mathematics. This is in accordance with the opinion of the Hashimoto (in Alim \& Jalinus, 2015) who said that open-ended learning provide more flexibility for students to highlight answers. The answers varied, it can be used to see the ability of creative thinking of students.

Open-ended questions can be used to determine students' creative thinking. It is expected to teachers to innovate in terms of questions so that students can improve the understanding of problems that they have never been done before. This process can improve students' thinking and reasoning, especially creative thinking. In accordance with the opinion of Cropley (in Wijaya, 2012:56), the ability of creative and innovative thinking as well as problem solving ability is a fundamental skill that is absolutely 
necessary in the 21st century. So that with an increase in creative thinking skills students are not left behind in the development of this modern era, where science is more advanced, and increasingly rapid technological and mathematical ability of students has increased.

\section{CONCLUSION AND SUGGESTIONS}

This study shows that students' creative thinking is low, because many students could not give many appropriate answers to the given open-ended mathematical problems. There is no student in the level of super creative.

The student in the creative category in general on all indicators is not to experience difficulties. He could understand the given problems and give as many correct answers. Students on the creative category experience some difficulties although they could give many answers, but such answers are not true. In addition, they only give similar answers to others. Students with the category of less creative are experiences many difficulties in resolving the problems. Many of them do not understand the given problem.

Related to implication of this study, we give advices to the parties relating to the research. Since this research is still limited to the discussion about the creative students, then it needs further research which discusses about how to improve students' competences to think creative. One also needs to understand how to develop a learning instruction to facilitate students' creative thinking.

\section{REFERENCES}

Alim, J. A. \& Jalinus. (2015). Pembelajaran Open-Ended Untuk Meningkatkan Kemampuan Pemecahan Masalah Matematika (Penelitian Eksperimen Pada Siswakelas IV SDN 034 Tarai Bangun Kecamatan Tambang Kabupaten Kampar). Jurnal Educational Community And Cultural Diversity, 2, 808-819

Fathurrohman. (2018). Mengenal Lebih Dekat Pendekatan dan Model Pembelajaran. Kalimedia. Yogyakarta. Mursidik, E. M., Samsiyah, N. \& Rudyanto, H. E. (2014). Analisis Kemampuan Berpikir Kreatif Siswa SD dalam Memecahkan Masalah Matematika Open-Ended Ditinjau Dari Tingkat Kemampuan Mtematika. Jurnal Penelitian LPPM, 2, (1), 7-13. http://ejournal.ikippgrimadiun.ac.id/index. $p$ hp/JP-LPPM

Kementrian Pendidikan Nasional (2006) Peraturan Menteri Pendidikan Nasional Republik Indonesia nomor 22 tahun 2006 tentang Standar Isi Untuk Satuan Pendidikan Dasar dan Menengah (The Regulation of the Republic of Indonesia government number 22 in 2006 concerning the content standards for units of basic and secondary education). The Ministy of National Edication of the Republic of Indonesia.

Ruslan, A. S. \& Santoso, B. (2013). Pengaruh Pemberian Soal OpenEnded Terhadap Kemampuan 
Penalaran Matematika Siswa. Jurnal Kreano, 4, (2), 138-150. http://journal.unnes.ac.id/nju/index .php/kreano/article/view/3138

Siegler, R. S., Duncan, G. J., DavisKean, P. E., Duckworth, K., Claessens, A., Engel, M., ... \& Chen, M. (2012). Early predictors of high school mathematics achievement. Psychological science, 23(7), 691-697.

Wijaya. (2012). Pendidikan Matematika Realistik: Suatu Alternatif pendekatan Matematika. Graha Ilmu. Yogykarta.

Witri, G., Putra, Z. H., \& Gustina, N. (2014). Analisis Kemampuan Siswa Sekolah Dasar Menyelesaikan
Dalam Soal-Soal
Matematika Model The Trends For International Mathematich And Science Study (TIMSS) Di Pekanbaru. Jurnal Primary PGSD FKIP UNRI, 3, (1), 32-39. https://dx.doi.org/10.33578/jpfkip.v $\underline{3 i 1.2111}$

Wulandari, F. (2017). Upaya Meningkatkan Kemampuan Berpikir Kreatif Siswa Melalui Pendekatan Open-Ended Pada Mata Pelajaran Matematka Dikelas IV MIN Miruk Taman Aceh Besar. (Skripsi). FTK. Universitas Islam Neger Ar-Raniry. Darussalam Banda Aceh. https://repository.arraniry.ac.id/1297/1/Fifi\%20Wulanda ri.pdf 